\title{
Modes of institutionalization in the Hare Krishna movement ${ }^{1}$
}

\author{
Vitor Hugo Adami \\ Universitat Rovira i Virgili \\ vitorhugoadami@gmail.com
}

\begin{abstract}
The purpose of this article is to consider the extent to which individuals are institutionalized by a religious tradition. I will base my discussion on Whitehouse's theory of 'modes of religiosity' and a brief description of three life histories of Western individuals who joined the Hare Krishna movement (ISKCON). I shall attempt to analyze how they use their knowledge of this tradition to readjust and reinterpret their religious beliefs and practices from the perspective of a local and global mode of institutionalization. I shall also briefly discuss these institutional dynamics which, at the same time, create equality and alterity so that individuals can possess a sense of both religious identity and belonging to a religious community.
\end{abstract}

Key wordsः Hare Krishna, identity, community, religious transmission.

Resumen: El objetivo de este artículo es realizar un análisis acerca de los modos de institucionalización a los cuales los individuos suelen pasar cuando están involucrados en una determinada tradición religiosa. Basándome teóricamente en la teoría de Whitehouse acerca de los 'modos de religiosidad' y, además, empíricamente, en tres historias de vidas de individuos occidentales que hacen parte de la tradición del movimiento Hare Krishna (ISKCON) intentaré analizar de qué manera, a través del conocimiento de dicha tradición, ellos readaptan y reinterpretan sus creencias y prácticas religiosas desde el punto de vista de un modo de institucionalización local y global. A partir de ahí finalizo con una breve consideración acerca de estas dinámicas institucionales que, al mismo tiempo, genera igualdad y alteridad a los individuos para poseer un sentido de identidad religiosa y, además, la pertenencia en la comunidad religiosa.

Palabras claves: Hare Krishna, identidad, comunidad, transmisión religiosa.

1 It is part of the full text presented at the 23rd European Conference on South Asian Studies (ECSAS) at the University of Zurich - Switzerland - during 23 to 26 July 2014.

2 Researcher of the project RELIG 2014 - AGAUR - in the Department of Anthropology at the Universitat Rovira i Virgili - Tarragona - Spain. 
I will start this text by making some inferences about our relationship with our inner selves, outer selves and others. I assume that there are three stages in socialization. The first is the one that makes us aware that 'we are' with no label at all. Perhaps we first become aware of this stage when we are born: the moment we open our eyes to take in and sense the reality around us. In this stage there are no concepts or labels, only the supposed fact that 'I AM'. I have assumed that this is the initial step in socialization because it is connected with the second stage: the perception of the self. As the first stage is considered to be the perception of the senses, the second is the perception of the self. This means that a being starts to perceive him/herself as a person - both the inner concept of 'me' and the perception of 'mine' - through interaction with an outside community. I will give an exampleः our families are the first communities which establish our possession of ourselves when they refer to us by our names. However, the collective selves surrounding us determine different social categories of our self-perception. This does not mean that our self-perception comes from a group of people, but from the intercommunication between what we think we are and what other people consider that we are supposed to be. By means of this communication process it can be shown that there is a system of knowledge and thoughts that supports the concepts of 'me', 'mine' and 'myself'. In other words, I assume here a religious tradition as a system of knowledge that permeates subjective and collective thoughts which impose the ways in which people not only perceive that they have a specific religious identity, but also connect with a religious community. This assumption is also considered in Cohen's studies (1994), when the author argues that we become communities by the imposition of social categories:

The state and other powerful social agencies compel us to compromise our individuality in our dealings with them by squeezing us into categories. The effect of this constraint is that we belong to society as members of collective entities (whether categories or groups) rather than as individuals. The application form compels me to render myself in ways which are not of my choosing. It would be a futile gesture to demand that whoever reviews my application for a passport or a driving license or a job or a club membership should consider - ME - the whole man. Instead, I have to comfort my conscious self into: husband; father of three sons; university professor; born in London; resident in Edinburgh; bearer of visible identifying features, 
etc., etc. My protest that these structural properties taken together do not add up to me are of no account: indeed, it is mark of my eccentricity. Our social membership requires us repeatedly to belittle ourselves in this way. Individuality and socialness seem to be in contradiction to each other (Cohen, 1994: 12).

In accordance with Cohen, the author cannot accept a notion of ME as a whole man based on social categories alone. It means that a sense of ME would exist beyond social categories as in the first stage of socialization argued above. The second stage - the sense's perception of "me" - and the third stage of socialization - the perception of "mine" through others - are surrounded by the imposition of different meanings of social categories which ourselves and others establish for us. This is a fundamental concept which social scientists have been debating ever since the advent of classical social theory, especially in Durkheim's and Mauss's studies. Cohen (1994) quoted Mauss's studies on the 'notion of person' as a 'social structure':

Mauss's concern with the person or self took the form of a cross-cultural review of the degrees of license afforded by cultures (and their legal and religious institutions) to individuals and individualism. He attempted to distinguish the moi [eu], the conscious self from the personne and the personage, the socially and culturally constituted personalities. However, he still focused, not surprisingly, on structure rather than experience; and his moi was a poor, attenuated creature, governed and determined by cultural rules. While the discrimination of terms he proposed was promising, he simply did not take it very far. His motivation may well have been linguistic rather than theoretical - that is, as an attempt to sort out the variety of terms available in French to refer to the first-person subject (none of which is a precise analogue of the English 'self'), rather than to render structuralism more sensitive to human experience (Cohen, 1994: 28).

Actually, Cohen's main criticisms of the classical social theorists were their limited focus on structure instead of experience, which makes the notion of $\mathrm{Me} /$ Self poor, because it was related only by the different meaning of the roles imposed by the social structure.

Using Cohen's argumentation, I will follow 'the path of self-experience' to give evidence of changes caused by the life experience of three social agents, who use their knowledge of the Gaudiya Vaishnavism tradition to readjust and 
reinterpret their religious beliefs and practices from the perspective of a local and global mode of institutionalization.

By global and local modes of institutionalization, I am referring to a kind of discourse. ${ }^{3}$ The global mode is the Hare Krishna movement's discourses, which are reproduced in different countries and on the Internet. ${ }^{4}$ The local discourse is the personal narrative of the devotees' experiences that are connected with the symbolism of this tradition where they live. However, to explain institutionalization, I assume any kind of knowledge to be part of an institution. And knowledge - in this case knowledge of a tradition - is a shared collective thought that might be discursively reproduced either globally or locally.

Broadly speaking, global institutionalization is observed when devotees all perform in the same way in the public sphere (that is to say in videos on internet, in the streets and in the temples around the world". One example would be when they "chant and dance Hare Krishna together". Local institutionalization is individual experience (personal experience) and it is perceived only by individuals where they live. These differences in institutionalization make it possible to distinguish the predominance of the individual over the collective and vice-versa and measure the extent to which knowledge of a religious tradition sustains believers. Below, on the basis of three interviews, I go further into what I mean by local and global institutionalization.

\section{Death as a symbol for RM Mataji and JB Mataji to exist in Krishna Consciousness}

I interviewed RM Mataji and JB Mataji when I was doing fieldwork at a Hare Krishna community (ISKCON temple) in Barcelona on March 30, 2009. They were two senior female devotees who have been living in Hare Krishna temples for more than twenty years.

The first interview was with RM Mataji, a lady who is nearly sixty years old. She was born in Holland and joined the Hare Krishna movement in 1988 in Amsterdam:

3 I use the term discourse as Potter does (1997:146). According to Potter discourse analysis, DA, 'emphasizes the way versions of the world, of society, events and inner psychological worlds are produced in discourse'. 4 I carried out fieldwork about the Hare Krishna movement in Brazil, Spain, England and India. This fieldwork led me to notice such a global discourse that I defined it as global institutionalization. 
Two matajis [female devotees] came to visit us. We were very impressed by the books. We decided to buy four of the books they showed us - the Bhagavad Gita and three cantos of Srimad Bhagavatam - and also a vegetarian cook book. We had already been vegetarians for many years. We gave a nice donation. And then they invited us for the Sunday feast. Two days later, we decided to go to Amsterdam and look for ourselves. We had never heard anything about Hare Krishna. But I found out that I had already been studying the Bhagavad Gita for two years. But the course was given by an impersonalist. He was a teacher giving a course on the Bhagavad Gita. I was very interested in philosophy. I went there every month, month after month of sessions. I was dissatisfied because I couldn't grasp what he really wanted to say. But when an impersonalist starts to explain the Bhagavada Gita you can't understand anything. I became more and more frustrated. And that moment, I was actually praying to God: 'If you exist can you please show me something that I can see with my eyes?' And the telephone was ringing. I was a little bit reluctant to pick the telephone up because I was a bit emotional. But I did. That was the first appointment.

It can be seen from the narrative above that RM Mataji and her husband were motivated by the Bagavad Gita because they found in it explanations that fitted the expectations of their belief system. In this case, I assume that the knowledge of this tradition has been privatized to suit their personal issues. What I want to make clear here is that a subjective experience has been adapted by the knowledge of a tradition. This means that people's lives can be changed not only by the structure of a tradition but also by personal experience. In their case, they were searching for a 'concept of god' which could be rationalized in their life context. Below is another narrative describing something about RM Mataji's life that was significant in defining her identity as a devotee:

For me Krishna Consciousness ... I was looking so much for absolute truth in my life. I looked in many different places. I was very eager, because when I was 36 years old I had a near death experience in a hospital during surgery and of course it was for some purpose. It was not happening for nothing. I had a very serious operation and I died. I saw everything happening on the monitor's screen. It flatlined, I died, I was watching and I was thinking, "OK, that's it." I didn't care about it. [... ] it happened. Because I went into the operation with the wrong consciousness and it happened. But I had to come out because the 
time was not right. [...] It was before I joined movement, and because all this happened to me I was more convinced to look for the truth. I was searching for information in libraries, books and shops. I wanted to find books about reincarnation. And of course you find a lot of books. I read a lot of books on this subject. It was true what happened there but you couldn't talk to anybody. They didn't believe me, not even the doctor.

RM Mataji's near death experience became a reality that has endured over time and has been transformed into a search for her personal truth. Here, I assume truth to be a kind of knowledge and in a previous study (Adami 2013) I refer to this kind of experience as an 'existential boundary experience' by which I mean an impact experience that integrates a form of knowledge into people's lives. This knowledge endures over time and defines meanings about identities and a sense of community. RM Mataji's narrative suggests that she found the answers she was looking for, her truth, in the tradition of the Hare Krishna movement (ISKCON). Through such an 'existential boundary experience' she was able to find a system of knowledge (the Hare Krishna movement) which allowed her to understand her personal truth. The experience was an 'encounter of knowledge' which supported her identify as a devotee and a member of the Hare Krishna community.

The second life story narrative also refers to death, in this case, in JB Mataji's Krishna consciousness. She says that she had to be reborn to Krishna consciousness in order to ultimately know the 'real meaning of happiness'. Before she knew Krishna consciousness, there was no sense of meaning in her life. She was unhappy with her family and friends because of an impact experience that she had been through when she was 16 :

When I was 16 I had a child who I gave up for adoption. But I didn't process the whole experience. I was very unhappy, I didn't know why. And I was looking for shelter, obviously. And I was stupid I could have done different things but I was completely blocked. I didn't have much faith in material happiness and at the same time I couldn't find a good spiritual alternative. [...] I was 19 when I first saw devotees on the street. When I was 18 in Canada, in Vancouver [first time]. I asked a friend who they were. She was into this impersonal thing. She said they were Hare Krishna, very high people. And then I said OK. But, finally some months later someone gave me a magazine; a devotee gave me a magazine. I couldn't afford to give any money but he gave 
me the magazine for free so I carried the magazine around with me. I didn't read it at first but I liked it, very colorful pictures.

When she met the devotees a second time she decided to follow them and become a Hare Krishna devotee:

I think it was Krishna. He was saying: 'Yes, that's what you are looking for' and I tried. 'This is exactly what you want' $[. .$.$] and another voice was saying$ Krishna is not god. I didn't like this voice. The other voice was very friendly, very kind so I listened to the right voice. The devotee asked me if I had any questions. He told me that it was not so easy to be a Hare Krishna. I replied by saying that anything was better than the life I was living. Finally, when I read this article I was ready. The time was right and I joined. I think it took me another, let me see, took me at least another 20 years before I could look back and clearly see the events that led to my journey. [... [ [What about the family?] They didn't... I left. That day my friend was sleeping in the apartment. I went there to get a few little things. I left her sleeping there [...] And my family didn't know where I was [...] Anyway now my connection with my family is very good, very, very good. Finally, it took a long time. First of all, it took a long time to find out where I was. Second, a clear understanding of the situation. Actually, they understood my reasons. I mean the family. The history was quite difficult so they haven't asked me why I left home, why I left everything. They know.

I have assumed that both life story narratives are about the sort of experiences that relate individuals to collective entities so that they can 'encounter' a meaning of identity and a sense of community. The term 'encounter' is used to express a 'social fact' that does not take place in only one direction. In other words, the meaning of identity and the sense of community are constantly negotiating their representation with each other. Each collective representation is a form of knowledge so that the individual can find institutionalization either subjectively or collectively. When the knowledge brought by the individual predominates over the knowledge of the religious tradition (collective representation), this is the private level of institutionalization, since the individual constructs his or her personal self-knowledge from the understanding of the religious tradition he or she is willing to follow. On the other hand, when the objective knowledge of a religious tradition predominates over the individual's subjectivity without impacting on his or her personal uniqueness, a public institutionalization takes 
place, as this form of institutionalization is the one given to everyone with no personal differentiation at all. I am not saying that these forms of representation take place in a linear sequence. Actually, they are used to measure the influence of the individual upon the community and vice-versa. The word predominance expresses the levels (subjective and objective) on which I am interested in displaying them so that the private and public institutional dimensions can be perceived.

So far, I have discussed how knowledge of the Krishna Consciousness tradition was transmitted to these devotees. Basically this sort of religious transmission is carried out by cognitive mechanisms. To explain the public and private institutionalization classification, Whitehouse's cognitive explanation of modes of religiosity is pertinent.

Whitehouse (2002) has identified two modes of religiosity which encompass two sets of dynamics. These dynamics involve the memories and the motivations that individuals and collectives use to engage in a religious tradition and remain part of it. The mechanisms of memory and motivation define the modes of religious transmission:

There are basically two kinds of memory: implicit and explicit (Graf and Schachter, 1985), implicit memory deals with things we know without being aware of knowing (such as the varied forms of procedural competence required in successfully riding a bicycle). Explicit memory deals with things we know at a conscious level, and can be further sub-divided into two types: shortterm and long-term. Short-term memory enables us to hold onto concepts for a matter of seconds (e.g., a new phone number, which we might remember just long enough to write it down before forgetting it). Long-term memory enables us to hold onto concepts for hours, and in some cases for a whole lifetime. Long-term memory can also be sub-divided into two types: semantic and episodic. Semantic memory consists of "general knowledge" about the world (e.g., how to behave in restaurants or what is the capital city of France, etc.). We can seldom recall how or when we acquired this sort of knowledge. By contrast, episodic memory consists of specific events in our life experience (e.g., our first kiss, the death of a beloved relative, the day war broke out, etc). These types of memory are activated very differently in doctrinal and imagistic modes of religiosity (Whitehouse, 2002: 296). 
The distinction between the doctrinal and imagistic modes of religiosity defined by Whitehouse can, theoretically, help to support the dynamics of the public and private institutionalization mentioned above:

One of the central characteristics of the doctrinal mode is the frequent repetition of both ritual and dogma. Many of the ceremonies performed, for instance, in the holy places of doctrinal religions, along with the reciting of texts, prayers, and liturgical formulae, are encoded in semantic memory. Routinization is directly connected to the style of codification: the implicational logic of doctrinal systems, expressed in language (sacred texts, sermons, theological debates, and so on), can only exercise a continuous and stable influence on people's attitudes, beliefs, and actions if it is frequently reviewed. The processing of religious materials in semantic memory has important sociological implications (Whitehouse, 2000: 9).

From another perspective, religion can be transmitted by the episodic memory, which leads to the imagistic mode:

By contrast, the rituals and images of the imagistic mode are primarily encoded in episodic memory. In many societies, religious life is focused around very infrequent, traumatic ritual episodes. Rites of initiation, for instance, commonly involve the terrorizing and torture of novices and the challenging of everyday knowledge through the partial transmission of esoteric revelations. Similar patterns may be identified in a variety of ideologically distinct religious systems (from climactic forms of millenarism to diabolical cults). The shock and arousal entailed in such contexts produce enduring episodic memories, and even classic flashbulb experiences. If you ask participants to describe what occurred in a given ceremony of this type several years afterwards, their accounts will not be based primarily on semantic knowledge. On the contrary, we would expect to be told exactly who the participants were, along with many peculiar details of their behavior. Common identity among religious adherents in the imagistic mode is fundamentally particularistic, based on lasting episodic memories of undergoing the traumatic lows and ecstatic highs of sacred events together with a specifiable group of individuals. The longevity and intensity of such memories corresponds to the strength and inviolability of the cohesion which they engender (Whitehouse, 2000: 10).

It is very important to make clear that Whitehouse (2004:75-76) did not say that a particular ritual, for instance, is doctrinal or imagistic. What the author 
says is that its long-term reproduction through the innumerable thoughts and actions of many people results in the coalescence of features specified by the modal theory. These features, in other words, are discernible only as marked tendencies within a religious tradition, taken in the round. What the theory of modes of religiosity sets out to explain, then, is the tendency for religious systems to gravitate toward divergent attractor positions.

Using Whitehouse's theory I have related the public mode of institutionalization to the doctrinal mode of religiosity and the private mode of institutionalization with the imagistic mode of religiosity. This means that if individuals are to be part of a religious tradition they need to be encompassed by both modes of institutionalization simultaneously.

The two life histories mentioned above describe a transmission of the Krishna consciousness tradition based on their episodic memory because it was connected with their existential boundary experience. These devotees were fully engaged in the organization ISKCON, and practically spent their whole lives serving 'Prabhupada's mission.' ${ }^{5}$ Actually, the transmission of the imagistic tradition creates strong links with the organization because the devotee is doing something that overarches his/her private, personal convictions. It is considered a private institutionalization because it is independent of the religious organization. The devotee can be part of a religious organization so that they can engage with the tradition privately.

The third life narrative is by an Indian-born British woman who has been living in London since her youth. I interviewed Ruckmini (24/08/2009) when I was doing fieldwork on Hindu communities in Harrow, London. I rented a room in her house so that I could live with her family for a while. Broadly speaking they considered themselves Hindus. However, Ruckmini pointed out that she used to consider herself a Hindu, but that nowadays she was a Krishna devotee and a member of the Hare Krishna movement, the International Society for Krishna Consciousness (ISKCON).

5 ISKCON is considered a branch of Gaudiya Vaishnavism. Srila Prabupada, an Indian spiritual master of Gaudiya Math, founded the organization in 1965 in New York. However, it became a westernized Indian organization as a reference to its own original tradition. See Adami (2012). 


\section{Ruckmini searching for philosophical comprehension for her meaning of life}

According to Ruckmini, Indian Hindus worship a variety of Hindu deities as part of their everyday life routine. Hindus do this out of habit and sometimes they are not aware of the 'real meaning' of their religious practice. In her case, when she was living in India (Gujarati) with her parents she used go to the swami Narayan's ${ }^{6}$ temple every day. At that time she didn't know why she had to worship the deities. She simply reproduced the performance that her parents obliged her to follow in the temple:

They didn't teach anything. There is nothing there basically. They just go to the temple to worship swami Narayan. There is no philosophy, there is no knowledge. They should say: you shouldn't drink, you shouldn't smoke, and you shouldn't eat meat... after a while nothing... They didn't talk about the soul, the good and bad or the three modes of material nature, or the spiritual soul or the incarnation... nothing!

In contrast, when Ruckmini started to visit the ISKCON temple in London, she noticed that there was a meaning to everything. At that time she was going through a conflict-ridden divorce. The classes on the Bhagavad Gita at the ISKCON temple were important for her because they allowed her to perceive the reasons for her suffering. She managed to cope with the whole conflict situation because of her knowledge of this tradition.

There are two important points in Ruckmini's religious transmission. The first is her membership of Swami Narayan's temple which she attended merely to satisfy her parents. However, when she had serious problems with her divorce, she began to attend a Hare Krishna temple where she found a meaning to her life and the explanation for some of the things that were happening in her life. The second point to be made is that the transmission of the religious tradition was in the imagistic mode because it was an 'encounter' of her personal subjectivity with the objectivity of the religious tradition. I regard this kind of encounter as a private institutionalization based on the imagistic mode of religiosity.

6 The Swami Narayan temple is also a Vaishnava tradition. It means that they worship Vishnu as Krishna. However, it is totally different than the Hare Krishna movement ISKCON. 
Very broadly speaking I have argued that these three people came to understand the meaning of their lives through the sense of being that Hare Krishna devotees believe to be established by the Gaudiya Vaishnavism tradition. There is a difference in perception when the individual grasps the meaning and follows the sense of the knowledge expressed by this religious tradition. The perception of the individual who becomes a devotee is always local, that is, in accordance with his or her local and private experience, which could be an impacting or existential boundary experience, as mentioned above, or an ordinary experience. When the tradition is understood as the result of a high-impact personal experience, the level of institutionalization in the religious tradition is very high. In other words, the tradition overarches all the facts of the individual devotee's life. It is a private institutionalization: the private experience of the devotee depends on understanding the religious tradition. It takes into account the alterity of the devotee. Alterity is conceived by his/her personal experience, the meaning of which is understood and adjusted to the devotee's own purposes through knowledge of the Gaudiya Vaishnava tradition. It is a private experience because only he/she can experience it. In the scenario of the religious tradition, devotees become the 'authors of the experience' (Adami, 2013) because they perceive what really matters in accordance with their personal experience.

The other mode of institutionalization into a religious tradition is the public one and I have defined this experience as 'the experience of the actor' (Adami, 2013). By understanding a religious tradition, the individual understands his/ her personal meaning of life and acts accordingly. However, in order to become part of a collective entity such as a religious community, the individual has to behave just like all the other members when they are in the temples, or on the streets chanting Hare Krishna (that is to say, when they are together in the public domain). This communal experience requires egalitarian performance and is conceptualized as the 'experience of the actor', because devotees must give the same performance to show a single underlying sense of being a devotee. I noticed this when I was doing fieldwork in Hare Krishna communities in Brazil, Spain, India, and England, especially when the devotees were gathered together. They would all behave in the same way to show a common idea underlying being a Hare Krishna devotee. It is an example of the public and global institutionalization of the knowledge of the Gaudiya Vaishnavism. 
I have given three examples of life history narratives. All the three devotees have experienced their alterity in accordance with their local context and they have also recognized their identities as global Hare Krishna devotees.

\section{Final considerations}

The issue I have been discussing - the way people can be institutionalized by a religious tradition - stems predominately from the individual approach. That's one of the reasons I have chosen the term 'private institutionalization' to describe those who change the perception of their own lives when they understand a religious tradition. In this case it does not matter whether it is a Hindu or a Christian tradition. What is relevant to our research is to map how people make their changes and to see how religion operates in their social interactions. I am not saying that the collective influence of a religious tradition (public institutionalization) is irrelevant. Rather, I want to show how the mutual interconnection between individuals and collective entities supports the structure of the religious institutionalization.

Focusing on the individual or private approach showed me that that the process of religious institutionalization does not alienate individuals or force them to act without personal coherence. As mentioned above, it is an "encounter of knowledge" through which the individual uses the knowledge offered by a religious tradition to provide his/her personal understanding with a meaning. In other words, the process of institutionalization into a religious tradition can be metaphorically considered by multifaceted discourses of knowledge.

At the beginning of the paper I made some inferences about how people can be institutionalized. In methodological terms, I suggested three categories for people who are socialized and made part of any institution. The first is the conception of inner self. This is the way an individual perceives that 'I AM'. In this perception there is no need to search for a category (label) to define the individual. However, it is embodied by 'sense perceptions' which lead to 'self-perceptions'. The second stage is 'self-perceptions', in which individuals find themselves searching for a 'ME' that can grasp an object and make it their own, like a possession. The third stage is 'the self through others' when individuals perceive their own selves through categories defined by others and recognize that 'WE ARE'. All of these forms are ways of being institutionalized 
in society. I have assumed that some dimensions would predominate over the institutionalization process. In the stages mentioned, the private level predominates in both the first and the second, while the public level completely predominates in the third stage. This fragmentation of predominance leads to a focus on individual performance and distinguishes the interconnection between individuals and collective entities. For example, private institutionalization involves searching for a private meaning of identity and its alterity. This meaning is based on the individual having a subjective experience in the place where he/she is living. The individual is the author of his/her experience. However, public institutionalization encourages individuals to perform the same actions so the individual experience resembles that of an actor who acts in response to a single meaning provided to everybody. Everybody tries to act like everybody else in order to keep a global sense of collectiveness.

I would like to clarify what I mean by the relation between private/ local experience and public/global experience. First of all in Lévy's studies (2007), I have noticed the importance of the conception of the universal without totality'. Lévy (2007:94) argued that the establishment of postmodernity led to some confusion in modern philosophy about what is conceived as universal with totality. According to Lévy, the universal tries to establish a unique sense for everything everywhere. However, this does not mean that it imposes the same meaning on everything in a totalitarian manner. A religious tradition is universal because it tries to give everybody a unique sense of belonging. Christians, Buddhists, Muslims, Jews, and Hare Krishnas are everywhere. All of these followers see themselves as part of a universal sense of religious tradition although this sense is not imposed by the traditions themselves.

Focusing more closely on my assumptions, the universal could be conceived as global. Both the universal and the global try to establish an unique sense that is common to everything everywhere. So I could add that the universal and global are categories of public institutionalization because they are permeated by an egalitarian ideal. I do not mean totalitarian. I will give an example: being part of any internet community is both universal and global. It offers the same sense of belonging to all individuals from different parts of the world. Broadly speaking, it is an example of public institutionalization.

However, Levy's thoughts on "the universal without totality" suggest to me that the meaning of the individual experience can also be singular, private and 
local. Everywhere and in every form of institutionalization, individuals engage in a universal (public) institution, but this does not mean that their meaning of belonging is the same. The meaning is totally different, singular, and private to each individual. For this reason the universal is without totality. The singularity of the individual's experience makes it a private institutionalization within the universal.

The levels of institutionalization in a religious tradition need to be classified if the accuracy of the data collected in a research study is to be improved. Focusing on social collective categories (public institutionalization) or atomic individuals (private institutionalization) is not the only true object of concern and analysis. The idea is to distinguish them and then map how individuals and their religious tradition can be transformed through their processes of private and public institutionalization.

I am aware that this article discusses nothing new. It can be regarded as a study in the 'pattern of religious conversion' tradition. However, I show here that a religious process of institutionalization cannot be avoided. If an individual understands that their life has religious meaning, they will become institutionalized. Whether or not they belong to a specific religious organization, however, the institutionalization - in the sense of knowledge of a religious tradition - has already been implanted in their minds as a collective thought.

Therefore, I do not agree with those authors who argue that in the contemporary world religion has undergone a process of deinstitutionalization. For example, Jean-Paul Willaime (1996) defends the idea that 'modernity is also a cultural destabilization of religion which is accompanied by a trend to deinstitutionalization'.

In his discussion of the classical thesis of the decline of religion and the more recent thesis of the privatization of religion, Casanova (1994:35) stated that once the religiosity of individuals shifts to the private sphere, it starts to undergo a process of deinstitutionalization. That is to say, the political links between ecclesiastical institutions and the attitudes and behaviors of individuals become laxer, which in practice means a substantial change in the expression and experience of religion.

In the 'contemporary religious world', then, believers and religious organizations can negotiate their mode of being institutionalized. However, the imperative of being institutionalized will always exist although to some 
extent it will depend on the circumstance and mode of institutionalization will be more or less public or private.

\section{References cited}

Adami, V.H. (2013), “O pensamento coletivo Hare Krishna e seus modos de institucionalização: um estudo sobre comunidades globalizadas e identidades locais". Tesis doctoral, Universitat Rovira i Virgili. Tarragona: <http://www.tdx.cat/handle/10803/132850>.

Adami, V.H (2012), "Modelos e Moldes de tradições: a hermenêutica do movimento Hare Krishna (ISKCON) sobre a tradição Gaudiya Vaishnava." Sacrilegens, 9 (2): <http://www.uff.br/sacrilegens/atual/artigo9-2-8/>.

Casanova, J. (1994), "Public Religions in the Modern World". Chicago: University of Chicago Press.

Conen, A.P. (1994), Self Consciousness-An alternative anthropology of identity. London: Routledge.

LÉvy, P. (2007), Cibercultura-informe al consejo de Europa. Rubí (Barcelona): Anthropos Editorial.

Graf, P; Schachter (1985), "Implicit and explicit memory for new associations in normal and amnesic subjects." Journal of Experimental Psychology: Learning, Memory, and Cognition, (11): 501-518.

Mauss, M. (2003), “Uma categoria do espírito humano: a noção de pessoa, a de 'eu' em Mauss, M. Sociologia e Antropologia. São Paulo: Cosac \& Naify.

Potter, J.'Discourse Analysis as a Way of Analysing Naturally Ocurring Talk', in D. Silverman (ed.), Qualitative Research: Theory, Method and Practice. London: Sage.

Whitehouse, H. (2002), "Modes of religiosity: towards a cognitive explanation of the sociopolitical dynamics of religion", Method E Theory in the Study of Religion, 14, 293-315.

Whitehouse, H. (2004), Modes of religiosity: a cognitive theory of religious transmission. Oxford: AltaMira press.

Willaime, J-P, (1996) “Dinámica religiosa y modernidad”, in G. Giménez (coord.), Identidades sociales y religiosas en México. Mexico, Instituto Francés de América Latina/Instituto de Investigaciones Sociales/UNAM: 47-65. 